\title{
Araştırma Makalesi/Research Article (Original Paper) \\ Bazı Türk Yazlık Ekmeklik Buğday Çeşitleri Arasındaki Genetik Farklılığın SSR Markörleriyle Belirlenmesi
}

\author{
Merve Dilek GEBOLOĞLU, Mehmet Alp FURAN* \\ Yüzüncü Yıl Üniversitesi, Ziraat Fakültesi, Tarımsal Biyoteknoloji Bölümü, Van, Türkiye \\ *e-posta: alpfuran@yyu.edu.tr; Tel: +90 (432) 4445065 / 22664
}

\begin{abstract}
Özet: Tahıllar içerisinde buğday, ilk çağlardan beri kültürü yapılan ve stratejik önemi yüksek olan bir besin kaynağıdır. Nüfusun artmasıyla birlikte birim alandan alınan verimi arttırma ihtiyacı doğmuştur. Buğdayda birim alandan alınan verimi arttırmak çeşitli sslah yöntemleri ile mümkün olabilir. Gen kaynaklarının genetik benzerlik-farklılıklarının bilinmesi bitki ıslahı açısından oldukça önemlidir. Son yıllarda buğdayda yapılan çalışmalarda moleküler markör yöntemleri sıklıkla tercih edilmektedir. Bu çalışmada, Türkiye'nin farklı bölgelerinden toplanan 23 adet ekmeklik buğday çeşidinin moleküler karakterizasyonunun belirlenmesi amaçlanmıştır. Bu amaçla 32 adet SSR primeri kullanılarak spesifik DNA bölgelerinin çoğaltılması sağlanmış ve kapillar yöntemle elektroforez işlemini gerçekleştirilmiştir. Yapılan moleküler markör analizi sonucunda çeşitler arasındaki genetik benzerlik ve farklılıklar moleküler düzeyde ortaya konmuştur. Ayrıca bu çalışmayla moleküler markör kullanımının ıslah çalışmaları için önemi ve gerekliliği bir kez daha vurgulanmıştır.
\end{abstract}

Anahtar kelimeler: Buğday çeşidi, Genetik Farklılık, Kapilar elektroforez, SSR primeri

\begin{abstract}
Wheat in grain, is a food source with high strategic importance and it was cultured since ancient times. Since the increase of population in the world, it was necessary in order to increase the yield per unit area. Increasing yield per unit area of wheat, can be achievable by various breeding methods. Knowing the genetic similarities - differences of plant genetic resources are very important for breeding. In recent years, molecular marker methods are often preferred in wheats. This study was aimed to molecular characterization of 23 bread wheat varieties which collected from different regions of Turkey using capillary electrophoretic method for 32 SSR primers. As a result of molecular marker analysis the genetic similarities and differences between the varieties are revealed at the molecular level. In addition, this study emphasizes once again the importance and necessity of using molecular markers for breeding studies.
\end{abstract}

Keywords: Wheat varieties, Genetic diversity, Capillary electrophoresis, SSR primer

\section{Determination of Genetic Diversity Among Some Turkish Spring Bread Wheat Varieties Using SSR Markers}

\section{Giriş}

Buğday (Triticum aestivum), çeltik (Oryza sativa L.), mısır (Zea mays L.), arpa (Hordeum vulgare L.) tüm dünyadaki nüfusun günlük kalori ihtiyacının yaklaşık \%80'ini karşılayan ve tarımı en çok yapılan tahıl türleridir (Okyay 2009). Tahıllar içerisinde buğday, ilk çağlardan beri kültürü yapılan ve stratejik önemi yüksek olan besin kaynağıdır. Dünya nüfusunun yaklaşık \%35'inin temel besin kaynağı olarak kullanılırlar. Ayrıca günlük ihtiyaç duyulan kalori miktarının yaklaşık \%20'sini karşılamaktadır. Buğdaydan, insan ve hayvan beslenmesinde de yararlanılmaktadır (Dede 2007). Buğday adaptasyon yeteneğinin yüksek, yetiştirilmesi-taşınması-depolanması kolay kültüre alınan ilk bitki olması nedeniyle geniş alanlarda yetiştirilmektedir. Buğday, insan beslenmesinde kullanılan kültür bitkileri arasında ekim alanı ve üretim miktarı bakımından Dünya'da ve ülkemizde önemli bir yere sahiptir (Yağdı 2004). TÜIKK 2015 verilerine göre; 7866.8874 hektar ekim alanında 22.6 milyon ton buğday üretilmiştir (TÜíK 2015). Buğdayın 
kimyasal bileşiminde; \%65-75 oranında karbonhidrat, \%7-18 oranında protein, $\% 8-14$ oranında su, $\% 8-14$ oranında lipit, \%1-2 oranında mineral maddeler ve iz miktarda da vitamin ve enzimler vardır. Ekmek üretiminde buğdayın tercih edilme nedeni bileşimindeki proteinlerin yaklaş1k \% $\% 5$ 'ini gluten proteinlerinin (Glutenin ve gliadin) oluşturmasıdır (Akyürek 2014). Ekmeklik buğday, [Triticum aestivum L. 2n=6x=42 (AABBDD)] her biri farklı atadan elde edilen üç genomu (A, B ve D) içeren allohekzaploid bir bitkidir

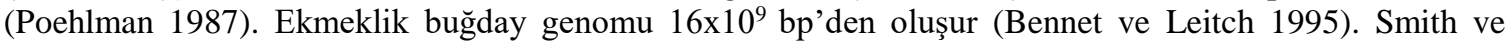
Flavell (1975), buğday genomunun \%80'inden fazlasının defalarca tekrarlanmış DNA sekansları içerdiğini belirlemişlerdir. Moleküler markörler değişik metodlarla tespiti yapılabilen polimorfik DNA sekanskodlama bölgeleridir (Metin 2012). Markör sisteminde bulunması gereken özellikler; kolay, hızlı ve ekonomik tespit edilebilmesi, polimorfik olması, kodominant kalıtım göstermesi, genomda düzgün bir şekilde dağılmış olması, ön sekans bilgisi olmayan genoma da uygulanabilmesi olarak açıklanabilir. Moleküler markörlerden, bitkilerde gen kaynaklarının özelliklerinin belirlenmesinde- genetik incelemelerde, bitki organizmalarında detaylı fiziksel ve genetik kromozom haritalarının çıkarılmasında, transgenik bitkilerin belirlenmesinde, bitkilerde istenilen özelliklerin seleksiyon yolu ile seçilmesi ve klasik ıslah çalışmalarında başarıyı arttırması gibi birçok alanda yararlanılmaktadır (Gupta ve ark. 1999; Atak 2004). Moleküler markörler; kontrollü tozlanmış melezlerin soylarını saptamak (Neale ve ark. 1992), önemli genotiplerin etiketlenmesi (Adams ve ark. 1988), bitki yetiştiriciliğinde genetik kaynakların kullanılması, aksesyonlar arasında ve içinde genetik farklılığın değerlendirilebilmesi (Melchinger 1999) için bitki ıslahçılarına imkan sağlar. Son yıllarda yapılan moleküler karakterizasyon çalışmalarında basit dizi tekrarlarına bağlı olarak geliştirilmiş mikrosatelit markörleri, diğer markör sistemlerine göre avantajlı olması nedeniyle daha sık tercih edilmektedir (Dede 2007). Bu çalışmada, Türkiye'nin çeşitli bölgelerinden toplanmış ve Türkiye'de yaygın olarak ekimi yapılan 23 yazlık ekmeklik buğday çeşidi arasındaki genetik farklılık ve benzerlikler SSR markörleriyle belirlenmiştir.

\section{Materyal ve Yöntem}

Bu araştırma, 2016 yılında Yüzüncü Yıl Üniversitesi Ziraat Fakültesi Tarımsal Biyoteknoloji Bölümü Laboratuvarı'nda yürütülmüştür. Çalışma materyalini oluşturan Türkiye'nin farklı bölgelerinden toplanmış 23 yazlık buğday çeşidi ve ıslah edildiği kuruluşlara ait bilgiler çizelge 1'de verilmiştir. DNA analizleri Yüzüncü Yıl Üniversitesi Ziraat Fakültesi Tarımsal Biyoteknoloji Bölümü'ne ait Uygulamalı Moleküler Genetik Laboratuvarı'nda yürütülmüştür. DNA'ların elde edilmesinde Doyle ve Doyle (1987) metoduna göre CTAB izolasyon yöntemi kullanılmıştır. PCR reaksiyonunda her örnekten eşit miktarda DNA kullanılmasını garantilemek amacıyla izole edilen çift iplikli DNA miktarının tayini Thermo NanoDrop 2000 cihazında yapılmış ve elde edilen ölçümler sonucunda hesaplanan DNA miktarı, PCR analizinde kullanılacak SSR markörleri için $\mu$ l'de 10 ng olacak şekilde TE (Tris-EDTA) tamponu ile seyreltilmiştir. PCR işlemi için, her tüpte toplam hacim $15 \mu$ l olacak şekilde; 50 ng genomik DNA, $200 \mu \mathrm{dNTP}$, ileri ve geri olmak üzere $(\mathrm{F}+\mathrm{R}) 1+1 \mathrm{pmol} /$ primer, $10 \mathrm{X}$ buffer ve $25 \mathrm{mM} \mathrm{MgCl}_{2}$, 5U/ $\mu \mathrm{l}$ Taq DNA polimeraz enziminden oluşmaktadır. PCR işlemi için ticari olarak sentezlenmiş uzunlukları 17-24 baz arasında değişen 103 SSR primeri başlangıçta tek genotipte denenmiş, screening sonuçlarına göre polimorfik ve tekrar edilebilir bant desenleri veren 32 adet SSR primeri kullanılmıştır. Kullanılan primerler ve baz dizilişleri çizelge 2'de verilmiştir.

Kapiler jel elektroforezinde PCR ürünlerinin görüntülenmesi amacıyla 25-500 bp (15 ng/ml) size marker ve $15-600$ bp alignment marker (20ng/ml) kullanılmıştır. Bant uzunluklarının maximum 500 bp olarak beklenmesinden dolayı OL1200 metodu kullanılmıştır. Elektroforez işlemi için Qiaxcell Screengel 1.4 yazılımı kullanılmıştır. Yazılım içerisinde injektion time 17 sn olarak ayarlanmış ve High Resulation DNA 1200 örneklik kit kullanılmıştır. 
Çizelge 1. Çalışmada kullanılan 23 buğday çeşidi

\begin{tabular}{ll}
\hline Genotip & Islah Edildiği Kuruluş \\
\hline Adana 99 & Çukurova Tarımsal Araştırma Enstitüsü/1999 \\
Alibey & Ege Tarımsal Araştırma Enstitüsü \\
Basribey 95 & Ege Tarımsal Araştırma Enstitüsü/1995 \\
Beşköprü & Sakarya Tarımsal Araştırma Enstitüsü/1997 \\
Cemre & GAP Uluslararası Tarımsal Araştırma ve Eğitim \\
& Merkezi/2008 \\
Çukurova & Çukurova Tarımsal Araştırma Enstitüsü/1986 \\
Cumhuriyet 75 & Ege Tarımsal Araştırma Enstitüsü/1975 \\
Doğankent 1 & Suriye-ICARDA/1991 \\
Hanlı & Misır Araştırma Enstitüsü Sakarya \\
Karacabey 97 & Mısır Tarımsal Araştırma Enstitüsü/1997 Sakarya \\
Karacadağ 98 & GAP Uluslararası Tarımsal Araştırma ve Eğitim \\
& Merkezi/1998 \\
Karatoprak & Çukurova Tarımsal Araştırma Enstitüsü \\
Kaşif Bey 95 & Ege Tarımsal Araştırma Enstitüsü/1995 \\
Menemen & Ege Tarımsal Araştırma Enstitüsü \\
Meta 2002 & Ege Tarımsal Araştırma Enstitüsü/2002 \\
Nurkent & GAP Uluslararası Tarımsal Araştırma ve Eğitim \\
Osmaniyem & Merkezi/2000 \\
Pamukova 97 & Çukurova Tarımsal Araştırma Enstitüsü \\
Seri 82 & Mısır Tarımsal Araştırma Enstitüsü/1997 Sakarya \\
Seyhan 95 & Çukurova Tarımsal Araştırma Enstitüsü \\
Tahirova 2000 & Çukurova Tarımsal Araştırma Enstitüsü/1995 \\
Yüreğir 89 & Mısır Araştırma Enstitüsü/2000 Sakarya \\
Ziyabey 98 & Çukurova Tarımsal Araştırma Enstitüsü/1989 \\
\hline
\end{tabular}

Çizelge 2. Çalışmada kullanılan 32 SSR primerinin isimleri, sekansları, toplam bant sayısı, polimorfik bant sayısı ve PIC değerleri

\begin{tabular}{|c|c|c|c|c|c|}
\hline Lokus & Sekans & $\mathrm{T}^{*}$ & $\mathbf{P}^{*}$ & $\mathbf{P \%}$ & PIC \\
\hline XGWM11 & $\begin{array}{l}\text { GGATAGTCAGACAATTCTTGTG } \\
\text { GTGAATTGTGTCTTGTATGCTTCC }\end{array}$ & 10 & 10 & 100 & 0.46805293 \\
\hline XGWM18 & $\begin{array}{l}\text { TGGCGCCATGATTGCATTATCTC } \\
\text { GGTTGCTGAAGAACCTTATTTAGG }\end{array}$ & 3 & 3 & 100 & 0.994328922 \\
\hline XBARC187 & $\begin{array}{l}\text { GTGGTATTTCAGGTGGAGTTGTTTTA } \\
\text { CGGAGGAGCAGTAAGGAAGG }\end{array}$ & 7 & 7 & 100 & 0.219551715 \\
\hline XBARC263 & $\begin{array}{l}\text { GGAAGCGCGTCAGCACTAGGCAAC } \\
\text { GGCTTCTAGGTGCTGCGGCTTTTGTC }\end{array}$ & 7 & 7 & 100 & 0.387523629 \\
\hline XGWM148 & $\begin{array}{l}\text { GTGAGGCAGCAAGAGAGAAA } \\
\text { CAAAGCTTGACTCAGACCAAA }\end{array}$ & 3 & 3 & 100 & 0.442344045 \\
\hline XGWM630 & $\begin{array}{l}\text { GTGCCTGTGCCATCGTC } \\
\text { CGAAAGTAACAGCGCAGTGA }\end{array}$ & 7 & 7 & 100 & 0.381852552 \\
\hline XGWM319 & $\begin{array}{l}\text { GGTTGCTGTACAAGTGTTCACG } \\
\text { CGGGTGCTGTGTGTAATGAC }\end{array}$ & 7 & 7 & 100 & 0.462597894 \\
\hline XGWM55 & $\begin{array}{l}\text { GCATCTGGTACACTAGCTGCC } \\
\text { TCATGGATGCATCACATCCT }\end{array}$ & 3 & 3 & 100 & 0.525519849 \\
\hline XBARC186 & $\begin{array}{l}\text { GGAGTGTCGAGATGATGTGGAAAC } \\
\text { CGCAGACGTCAGCAGCTCGAGAGG }\end{array}$ & 11 & 11 & 100 & 0.369822994 \\
\hline XGWM234 & $\begin{array}{l}\text { GAGTCCTGATGTGAAGCTGTTG } \\
\text { CTCATTGGGGTGTGTACGTG }\end{array}$ & 4 & 4 & 100 & 0.530245747 \\
\hline WMC156 & $\begin{array}{l}\text { GCCTCTAGGGAGAAAACTAACA } \\
\text { TCAAGATCATATCСTCСССАAC }\end{array}$ & 5 & 4 & 80 & 0.325519849 \\
\hline
\end{tabular}


(Çizelge 2 devamı)

\begin{tabular}{|c|c|c|c|c|c|}
\hline WMC326 & $\begin{array}{l}\text { GGAGCATCGCAGGACAGA } \\
\text { GGACGAGGACGCCTGAAT }\end{array}$ & 8 & 7 & 87.5 & 0.4213138 \\
\hline WMC327 & $\begin{array}{l}\text { TGCGGTACAGGCAAGGCT } \\
\text { TAGAACGCCCTCGTCGGA }\end{array}$ & 6 & 6 & 100 & 0.262129805 \\
\hline WMC261 & $\begin{array}{l}\text { GATGTGCATGTGAATCTCAAAAGTA } \\
\text { AAAGAGGGTCACAGAATAACCTAAA }\end{array}$ & 5 & 5 & 100 & 0.371266541 \\
\hline WMC276 & $\begin{array}{l}\text { GACATGTGCACCAGAATAGC } \\
\text { AGAAGAACTATTCGACTCCT }\end{array}$ & 10 & 10 & 100 & 0.270510397 \\
\hline WMC27 & $\begin{array}{l}\text { AATAGAAACAGGTCACCATCCG } \\
\text { TAGAGCTGGAGTAGGGCCAAAG }\end{array}$ & 4 & 4 & 100 & 0.388468809 \\
\hline WMC63 & $\begin{array}{l}\text { GTGCTCTGGAAACCTTCTACGA } \\
\text { CAGTAGTTTAGCCTTGGTGTGA }\end{array}$ & 6 & 6 & 100 & 0.424700693 \\
\hline WMC96 & $\begin{array}{l}\text { TAGCAGCCATGCTTAGCATCAA } \\
\text { GTTTCAGTCTTTCACGAACACG }\end{array}$ & 7 & 7 & 100 & 0.377801782 \\
\hline WMC44 & $\begin{array}{l}\text { GGTCTTCTGGGCTTTGATCCTG } \\
\text { TGTTGCTAGGGACCCGTAGTGG }\end{array}$ & 5 & 3 & 60 & 0.435916824 \\
\hline WMS108 & $\begin{array}{l}\text { ATTAATACCTGAGGGAGGTGC } \\
\text { GGTCTCAGGAGCAAGAACAC }\end{array}$ & 5 & 4 & 80 & 0.434782609 \\
\hline WMC175 & $\begin{array}{l}\text { GCTCAGTCAAACCGCTACTTCT } \\
\text { CACTACTCCAATCTATCGCCGT }\end{array}$ & 2 & 2 & 100 & 0.269376181 \\
\hline WMC153 & $\begin{array}{l}\text { ATGAGGACTCGAAGCTTGGC } \\
\text { CTGAGCTTTTGCGCGTTGAC }\end{array}$ & 12 & 12 & 100 & 0.188563327 \\
\hline WMC154 & $\begin{array}{l}\text { ATGCTCGTCAGTGTCATGTTTG } \\
\text { AAACGGAACCTACCTCACTCTT }\end{array}$ & 2 & 2 & 100 & 0.791115312 \\
\hline WMC322 & $\begin{array}{l}\text { CGCCCCACTATGCTTTG } \\
\text { CCCAGTCCAGCTAGCCTCC }\end{array}$ & 8 & 8 & 100 & 0.498582231 \\
\hline WMS30 & $\begin{array}{l}\text { ATCTTAGCATAGAAGGGAGTGGG } \\
\text { TTCTGCACCCTGGGTGATTGC }\end{array}$ & 3 & 2 & 66.7 & 0.661625709 \\
\hline WMS375 & $\begin{array}{l}\text { ATTGGCGACTCTAGCATATACG } \\
\text { GGGATGTCTGTTCCATCTTAGC }\end{array}$ & 3 & 3 & 100 & 0.112161311 \\
\hline WMC25 & $\begin{array}{l}\text { TCTGGCCAGGATCAATATTACT } \\
\text { TAAGATACATAGATCCAACACC }\end{array}$ & 3 & 3 & 100 & 0.419029616 \\
\hline WMC147 & $\begin{array}{l}\text { AGAACGAAAGAAGCGCGCTGAG } \\
\text { ATGTGTTTCTTATCCTGCGGGC }\end{array}$ & 7 & 7 & 100 & 0.480691331 \\
\hline WMC445 & $\begin{array}{l}\text { AGAATAGGTTCTTGGGCCAGTC } \\
\text { GAGATGATCTCCTCCATCAGCA }\end{array}$ & 5 & 5 & 100 & 0.330056711 \\
\hline WMC47 & $\begin{array}{l}\text { GAAACAGGGTTAACCATGCCAA } \\
\text { ATGGTGCTGCCAACAACATACA }\end{array}$ & 6 & 6 & 100 & 0.442659105 \\
\hline WMC43 & $\begin{array}{l}\text { TAGCTCAACСACСACССТACTG } \\
\text { ACTTCAACATCCAAACTGACCG }\end{array}$ & 1 & 1 & 100 & 0,243856333 \\
\hline WMC97 & $\begin{array}{l}\text { GTCCATATATGCAAGGAGTC } \\
\text { GTACTCTATCGCAAAACACA }\end{array}$ & 4 & 4 & 100 & 0.200378072 \\
\hline Toplam & & 179 & 174 & & \\
\hline Ortalama & & 5.59 & 5.43 & 96.07 & \\
\hline
\end{tabular}

\section{İstatistiksel analiz}

Genotipler arasındaki genetik benzerlik ve genetik uzaklık değerlerinin hesaplanmasında, SSR bantlarının sayılması ve varlıklarına göre bant adetlerinin rakamsal olarak değerlendirilmesi ile hazırlanmış olan binari veri matriksinden faydalanılarak Nei and Li (1979)'nin aşağıdaki formülü kullanılmış ve NTSYS-pc 2.0 (Rohlf 1998) software programı aracılığıyla genotiplere ait dendrogram elde edilmiştir. Polimorfizm bilgi içeriğinin hesaplanmasında PIC $=1$ - इpi2. Formülü kullanılmıştır (Riek 2001). 


\section{Bulgular ve Tartışma}

Görüntü alınan DNA fragmentlerinin değerlendirilmesi amacıyla Qiaxcell Screengel 1.4 yazılımı kullanılmıştır. Bantların hizalama işlemleri alignment marker (hizalama markör) ile gerçekleştirilmiştir. Her bir bant için yazılımda verilen $\mathrm{ng} / \mathrm{ml}$ oranlarındaki konsantrasyonlarına bağlı olarak verilen pik değerleri alınıp, PCR ürünlerinden elde edilen bantların baz uzunluklarının belirlenmesi işlemi de Qiaxcell Screengel yazılımı ile elde edilmiştir. Var olan bantların allel bölgelerine göre binomial veriler bantların baz uzunluklarına göre elde edilmiştir. Yazlık çeşitler arasındaki ilişkinin saptanması amacıyla kullanılan 32 SSR primerinin kapiler jel elektroforezindeki görüntüleri ve elde edilen konsantrasyona bağlı uzunluk değerlerini temsili jel görüntüleri şekil 1 ve şekil 2'de verilmiştir.

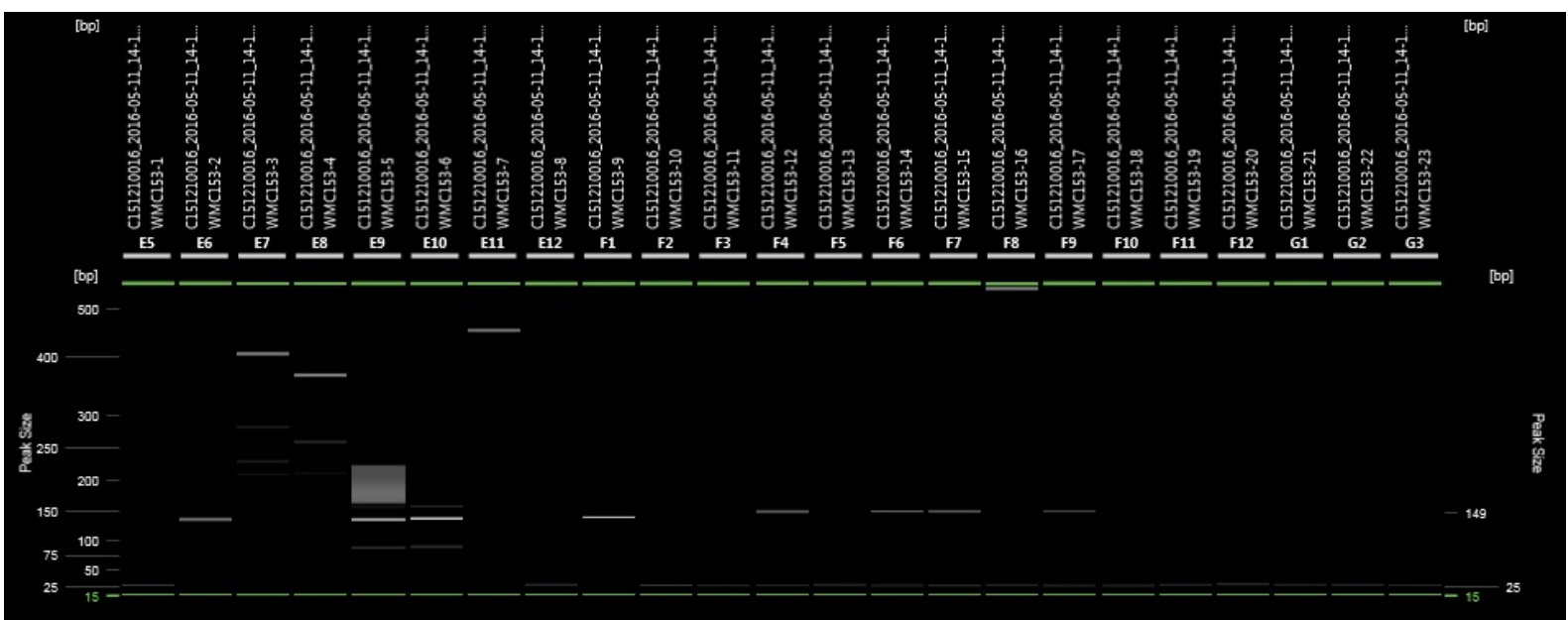

Şekil 1. WMC153 primerinin kapiler jel elektroforezindeki görüntüsü.

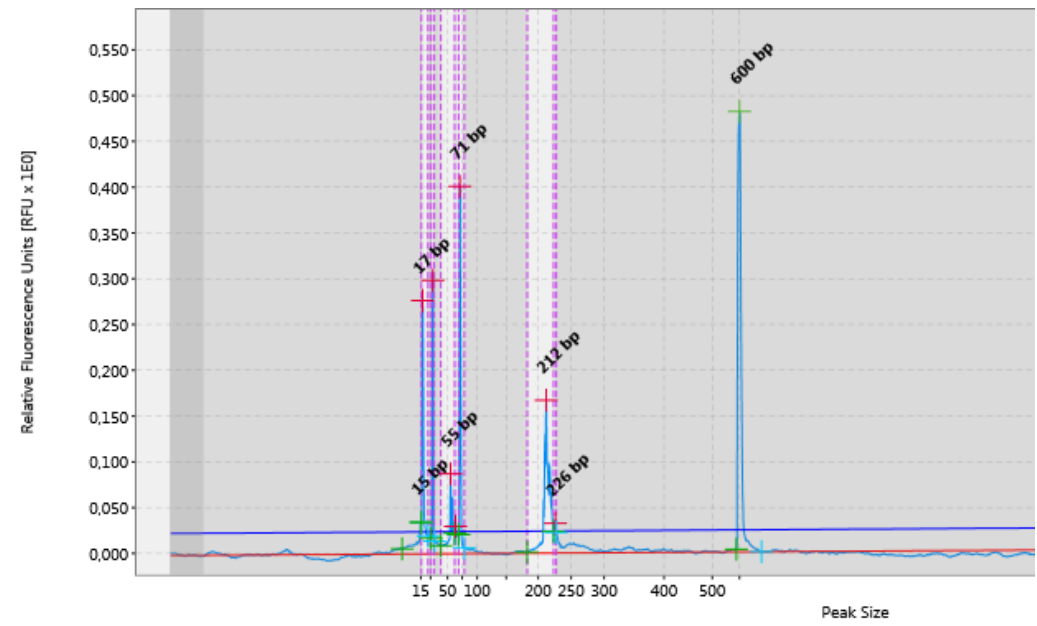

Şekil 2. Konsantrasyona bağlı uzunluk değerleri jel peak görüntüsü.

WMC327 Primerinin Adana 99, Alibey, Basribey95, Beşköprü, Cemre, Çukurova, Cumhuriyet 75, Doğankent 1, Hanlı, Karacabey 97, Karacadağ 98 ve Karatoprak çeşitlerinde gösterdiği pik değerleri

Çalışmada 32 SSR primeri kullanılmış, çalışma sonucunda yapılan analizlerde 174 polimorfik 5 monomorfik olmak üzere toplamda 179 skorlanabilir bant elde edilmiştir. Primer başına ortalama 5.59 bant olmak üzere 1 (WMC43) ile 12 (WMC153) arasında değişim göstermiştir (Çizelge 2). Ortalama polimorfik bant sayısı primer başına 5.43 olmak üzere maksimum polimorfik bant sayısı (12 bant) WMC153 primerinden elde edilirken, minimum polimorfik bant sayısı (1 bant) WMC43 primerinden elde edilmiştir 
(Çizelge 2). Polimorfizm yüzdesi tüm genotiplere arasında \%96.07'lik bir ortalama ile \%60’tan \% 100’lere varan bir değişim göstermektedir.

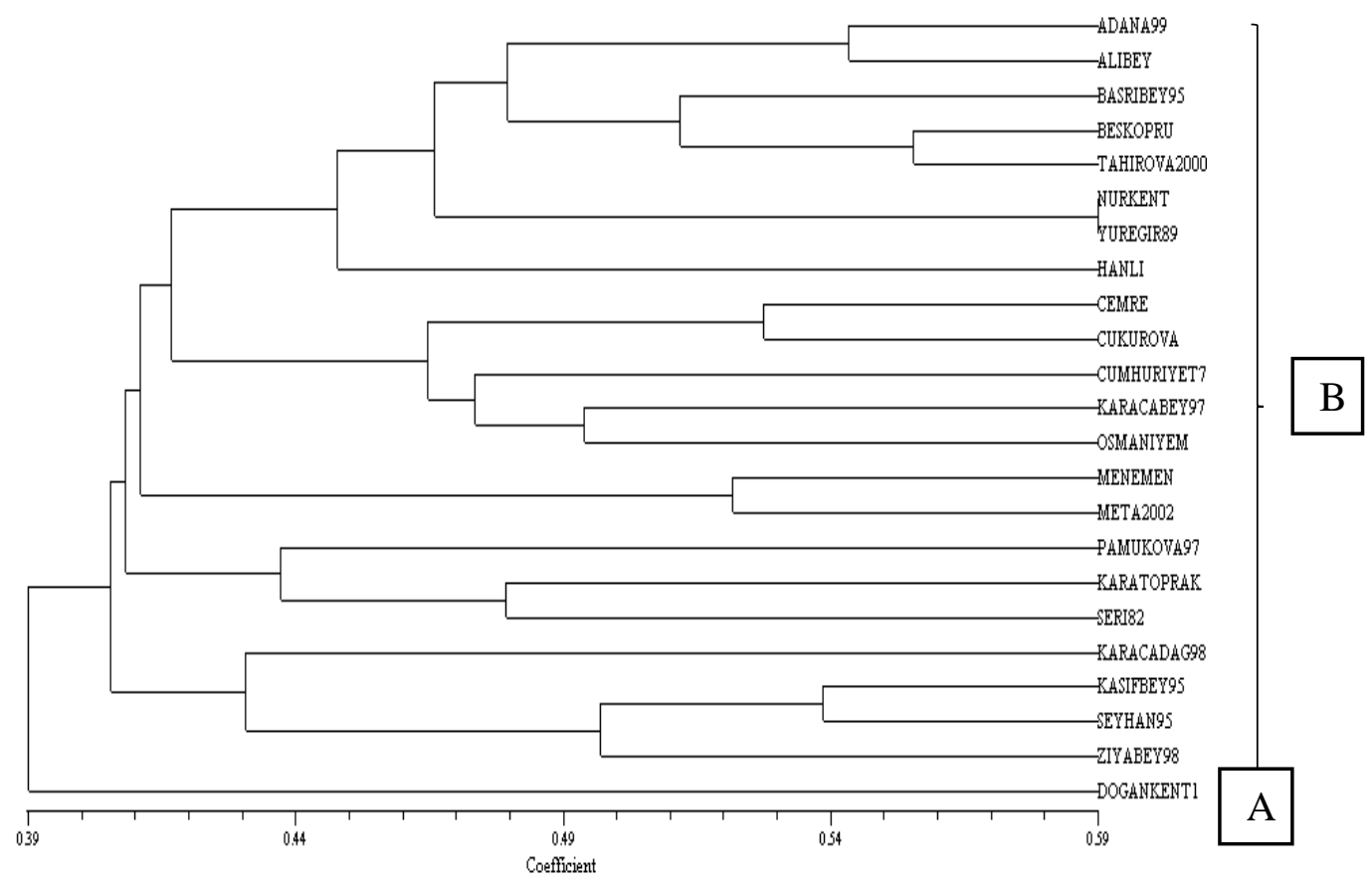

Şekil 3. SSR markörleri ile yapılmış 23 buğday genotipine ait dendogram.

23 yazlık buğday çeşidinden elde edilen bantların oluşturduğu binary veri setine uygun olarak hazırlanmış dendogram incelendiğinde (Şekil 3) genotipler A ve B olmak üzere iki ana gruba ayrılmıştır. Doğankent 1 genotipi tek başına A grubunda yer alırken diğer genotipler ise B grubuna dahil olmuştur. B grubunda yer alan genotipleri ise 5 ayrı alt grup altında değerlendirmek mümkün olmuştur. Doğankent 1 çeşidinin diğer yazlık buğday çeşitlerinden ayrıldığı görülürken Adana 99, Alibey, Basribey 95, Beşköprü, Tahirova 2000, Nurkent, Yüreğir89 ve Hanlı çeşitlerinin birbirlerine yakın ortak bir grup oluşturdukları yine aynı şekilde Cemre, Çukurova, Cuhuriyet 75, Karacabey 97 ve Osmaniyem çeşitlerinin bir diğer alt grubu oluşturduğu görülmektedir. Menemen ve Meta 2002 çeşitlerinin birlikte yer alması yanı sıra Pamukova97, Karatoprak, Seri 82 çeşitlerinin bir arada yer aldığı, Karacadağ 98, Kaşifbey 95, Seyhan 95 ve Ziyabey 98 çeşitlerinin ise birlikte aynı grup altında toplandığı görülmüştür. Yapılan analizler sonucunda çeşitler arasındaki genetik farklılığın toplandıkları bölgelerden kaynaklandığ görülmektedir. A grubuna ait tek genotip olan Doğankent 1 çeşidine bakıldığında ıslah edildiği kuruluşun Suriye/ICARDA olduğu görülmektedir. B grubuna ait genotiplere bakıldığında, çeşitlerin ıslah edildikleri kuruluşların Türkiye genelindeki kuruluşlar olduğu görülmektedir. Bununla birlikte tüm primerlerin oluşturduğu dendograma bakıldığında, aynı alt gruba giren Menemen ve Meta 2002'nin aynı yerde 1slah edildikleri görülmektedir (Çizelge 1). Oluşturulmuş Dendogram göz önüne alındığında farklı bölge çeşitlerinin de aynı alt gruplarda bulunması, genetik farklılıkta coğrafik bölgelerden başka etkenlerin de olduğunu göstermektedir. Strelchenko ve ark. (2004), 22 farklı ülkeden topladığı 78 yerel çeşitte SSR markörleriyle farklılığı belirlemeye çalışmış, sonuçta genetik farklılığa baktıklarında aynı coğrafik bölgeden gelen genotiplerin aynı alt gruplara girdiğini; farklı coğrafik bölgelerden alınan çeşitlerinde aynı alt gruba girebildikleri gibi farklı alt gruba da girebildiklerini belirtmişlerdir. Bu durum genetik tabandaki çeşitliliğin sonucu olarak açıklanabilir.

\section{Sonuç}

Buğday geniş adaptasyon yeteneğine sahip olması ve insan beslenmesinde sıklıkla kullanılması nedeniyle oldukça önemli bir bitkidir. Ayrıca dünyada ve Türkiye'de ekiliş-üretim sıralamasında ilk sıralarda yer almaktadır. Ancak son yıllarda buğdayda genetik varyasyon daralmaktadır. Bu çalışma buğdayda daralan genetik varyasyona çözüm olabilecek bazı Türk yazlık ekmeklik buğday çeşitlerinin seçiminin 
kolaylaştırılması ve bu çeşitlerle ileride yapılabilecek ıslah çalışmalarına faydalı veriler sağlaması açısından önemlidir. $\mathrm{Bu}$ çalışma da bu yönüyle ileriki bitki 1slah programlarında kullanılabilir olma niteliği taşımaktadır. Bu çalışma sayesinde ülkemiz açısından oldukça büyük öneme sahip yazlık ekmeklik buğday çeşitlerinin DNA parmak izlerinin kapilar elektroforetik yöntemle belirlenmesi faydalı bir zemin oluşturmuştur. Çalışmadan elde edilen sonuçlara göre yazlık ekmeklik buğday çeşitlerinin tanımlama ve sınıflandırmalarının yapılabilmesi için SSR markörlerinin kullanılabileceğinin yararlı ve kullanışlı olduğu kanıtlanırken, bu çalışma sonucunda elde edilen veriler ışığında, belirli özelliklere ve genlere yönelik yürütülmesi planlanacak yeni ıslah projeleri için faydalı sonuçlar kullanılabilir veriler haline getirilmiştir.

\section{Kaynaklar}

Akyürek S (2014). Değişik Fenolojik Özelliklere Sahip Buğday Çeşitlerinde Süne Zararının Verim ve Kalite Üzerine Etkisi ve Genetik Farklılıkların Belirlenmesi. (Doktora Tezi) Namık Kemal Üniversitesi Fen Bilimleri Enstitüsü, Tarla Bitkileri Ana Bilim Dalı, Tekirdağ.

Atak M (2004). Farklı Triticale Hatlarının Morfolojik ve DNA Markörleriyle Genetik Karakterizasyonu. (Doktora Tezi, yayınlanmamış). Ankara Üniversitesi, Fen Bilimleri Enstitüsü, Tarla Bitkileri Anabilim Dal1, Ankara.

Bennett MD, Leitch IJ (1995). Nuclear DNA amounts in angiosperms. Ann. Bot., 76: 113-176.

Dede B (2007). Mikrosatellit DNA Belirleyicileri Kullanarak Yerel Ekmeklik Buğday Çeşitlerinin Tanımlanması (Yüksek Lisans Tezi). Gazi Osman Paşa Üniversitesi, Fen Bilim. Enstitüsü, Tokat.

De Riek J, Calsyn E, Everaert I, Van Bocksteal E, De Loose M (2001). AFLP based alternative for the assessment of the distinctness, uniformity and stability of sugar beat varieties. Theor. Appl. Genet. 103: $1254-1256$.

Doyle JJ, Doyle JL (1987). A rapid DNA isolation procedure for small quantities of fresh leaf tissue. Phytochem. Bull., 19: 11-15.

Gupta PK, Varshney RK, Sharma PC, Ramesh B (1999). Review. Moleküler Markers and Their Application in Wheat Breeding. Plant Breeding, 118: 369-390.

Melchinger AE (1999). The Genetics and Exploitation of Heterosis in Crops. Genetic diversity and heterosis (Editor: . In J.G. Coors and S. Pandey) CSSA, Madison, WI. S:99-118.

Metin A (2012). Nohut Çeşitlerinde SSR Varyasyonu ve Genetik İlişkilerin Değerlendirilmesi (Yüksek Lisans Tezi). Bozok Üniversitesi Fen Bilimleri Enstitüsü, Yozgat.

Neale DB, Devey ME, Jermstad KD, Ahuja MR, Alosi MC, Marshall KA (1992). Use of DNA markers in forest tree improvement research, New. For., 6: 391-407.

Nei M, Li WH (1979), Mathematical model for studying variation in terms of restriction endonucleases. Proc. Nat. Acad. Sci., 76: 5269-5273.

Okyay VV (2009). Akdeniz Bölgesine Uygun Ekmeklik Buğdaylarda (Triticum aestivum L.) Dgenomundaki Değişimlerin SSR Markörleri Yoluyla Belirlenmesi (Yüksek Lisans Tezi). Mustafa Kemal Üniversitesi Fen Bilimleri Enstitüsü, Antakya/Hatay.

Poehlman JM (1987). Breeding Field Crops $3^{\text {rd }}$ edition. AVI, Westport, Connecticut.

Prasad M, Varshney RK, Roy JK, Balyan HS, Gupta PK (2000). The use of microsatellites for detecting DNA polymorphism, genotype identification and genetic diversity in wheat. Theor. Appl.Genet., 100: 584-592.

Rohlf FJ (1998). NTSYS-pc: Numerical Taxonomy and Multivariate Analysis System, Version 2.0, User's Guide. New York: Exeter Software.

Smith DB, Flavell RB (1975). Characterisation of the wheat genome by renaturation kinetics. Chromosome, 50: 223-242.

Strelchenko P, Street K, Mitrofanova O, Mackay M, Balfourier F (2004). Genetic diversity among hexaploid wheat landraces with different geographical origins revealed by microsatellites: Comparison with AFLP and RAPD. $4^{\text {th }}$ International Crop Science Congress, Eylül 2004, Brisbane/Avusturalya.

TÜİK (2015). Bitkisel ürün istatistikleri. http://www.tuik.gov.tr/PreTablo.do?alt_id=1001. Erişim Tarihi: 4.06.2016.

Yağdı K (2004). Bursa Koşullarında Geliştirilen Ekmeklik Buğday (Triticum aestivum L.) Hatlarının Bazı Kalite Özelliklerinin Araştırılması. Ulud. Üniv. Zir. Fak. Derg., 18(1): 11-23. 